\title{
Business Sustainability based on Sustainability and Islamic Ethics Practice
}

\author{
Nunung Ghoniyah ${ }^{1}$, Farikha Amilahaq ${ }^{2}$ \\ Universitas Islam Sultan Agung, Semarang City, Indonesia ${ }^{1,2}$ \\ \{nunung@unissula.ac.id ${ }^{1}$, farikha@unissula.ac.id ${ }^{2}$ \}
}

\begin{abstract}
The aim of this study is to emphasize the relationship between global sustainable goals and sustainable business goals. So that the two goals can run in harmony without colliding with each other because of differences in interests. The sustainability goals and business way for achieving business sustainability. For Muslims, those are inseparable from the purpose of humanity as caliphs on earth, and also the ways to acheive them are must refer to Islamic provisions. Therefore this study also intends to integrate elements of global sustainability, business patterns, and Islamic principles into a comprehensive scheme, from procedures (intentions, goals, and actions in accordance with Islamic principles) to achievement targets (sustainability and sustainability business). The results of this study provide a scheme that needs to be tested for correlation, especially in Islamic based institutions, such as Islamic universities, Islamic hospitals, and other companies that use Islamic values as corporate values.
\end{abstract}

Keywords: Islamic Business Ethics, Islamic Work Ethics, Sustainability Awareness, Business Sustainability, Islamic Corporates

\section{Introduction}

The main purpose of a business should not be high profit, but the company's ability to run the business countinously [1]. The high profit in the current period does not ensure the corporate will still operate in the long term. While the capability of the firm to keep running the business in the long term will ensure the continuous return [2]. Such condition is called as business sustainability.

A sustainable business should not focus only to the interests of the company itself such as high profits, low costs, faster turnover, etc. The corporate must also care to the acceptance of the community about the existence of the corporation [1]. Therefore, the company's responsibility for the surrounding environment is very important. This revolution of interest is proven by the development of shareholder theory to the stakeholder theory [1]. Finally, it brings up a regulation that make the companies must do corporate social responsibility. Furthermore, social orientation is now considered by many parties in the world through the Sustainable Development Goals agenda (global sustainability goals) [3].

Research in the hotel sector emphasizes the importance of maintaining sustainability, including the impact of their company in the future (the business sustainability). Optimal service in the hospitality service sector is not number one, but the concern to minimize waste 
as a form of maintaining sustainability for the future [4]. As for the research involve business ethics on the service standards, also related to policies that lead to legal and good policies (in Islam it is called Halal and Toyyib). It means the ways to achieve business sustainability is by the proper business ethics [4]. Ethical-based policies tend to provide the legal actions, but it is still uncertain whether good or not. Because ethical standards will be different depending on the culture and norms believed in each region [5]. Business ethics standards sourced from human thinking is not enough. Thus it is necessary to include good values as a stronger control than just the elements of legality and norms [5].

Islam is a religion that not only regulates the relationship between humans and God, but also regulates the relationship among humans, as well as humans with the surrounding environment. This is written in the Islamic holy book namely Al Qur'an. The Qur'an, along with the Sunnah and Hadith of the Prophet Muhammad Peace be upon him (PBUH), is the main source of reference that governs all human actions. Moreover, it has been stipulated in the Qur'an that the purpose of mankind is to worship Allah SWT, and to become a caliph on earth. The humans' objective as caliph is in line with the goal of sustainability, it is to guard the earth.

A Muslim in playing his role on earth, both as an employer and as an employee, not only needs to pay attention to the halal and prohibition of what he does, but also to pay attention to the ethical, wrong and right, good and bad, fair and unfair, and even need to pay attention to in terms of their intentions and goals [5]. Therefore, the right business ethics in an effort to achieve both business continuity and the sustainability, is the business ethics involving the Islamic principle. As for the Islamic principle must be implemented in the business ethics and the workers'.

In Indonesia, this concept becomes very important to be applied because the majority of the population of Indonesia is Muslim. It is unwise when we separate religious affairs from world affairs (secularism). Because basically Islam exists to be a guide in carrying out any actions relating to worship (ibadah) and actions related to world affairs such as working, doing business, cooperating, or behaving to others and the environment (muamalah). Moreover, managing a business that is in accordance with Islamic values can benefit Muslim and non-Muslim managers; those are by better understanding how to treat Muslim employees as a more humane policy of human resources, and by better understanding Muslim businessmen so that the manager can find a proper cooperation strategy, which ultimately can maintain the sustainability of the company [5]. Based on some previous researchers, the schema of the relationship between Islamic ethics, sustainability and business sustainability can figure out as follows.

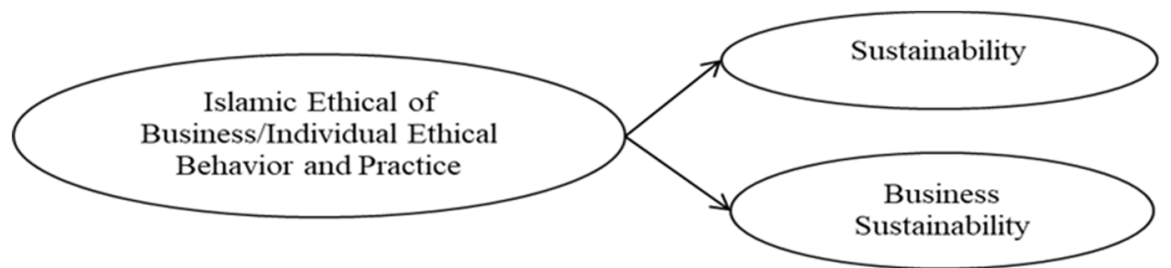

Fig. 1. Relationship Scheme based on Previous Researches

Sources : : [4]-[6]

Description: [5] proposes the concept of Islamic ethics, [4] suggests the relationship of ethics with sustainability, and [6] suggests the relationship between business ethics and business sustainability 
This research is a continuation of previous research related to the role of companies (banking) towards global sustainability goals [2]. Islamic banking as a company that applies sharia principles in running its business, faces obstacles to contribute to global sustainable goals. Islamic banking in Indonesia can be said to have a young age and have a very small market capitalization compared to conventional banks. This is because they are still in the phase of maintaining their business continuity. Thus the result showed that the sharia banking unable contribute to the sustainability goals as well as the conventional bank. The previous research also used the ratio data of Islamic companies to measure the relationship between the work of Islamic companies and global goals. So it is necessary to have research that involves elements of ethics, company vision, and human resources. Those elements should can reflect better about the role of Muslims entity as caliph on the earth.

\subsection{Problem Statement}

Based on the introduction presented, several problem statements appear as follows.

a) In the scheme presented in Figure 1, there is still a gap between the sustainability goals and the interests of the company to maintain their business sustainability.

b) As for the previous research, sustainability goals were discussed more based on a natural and environmental issue, while the objectives for the social and economic pillars have not been mentioned much.

c) Moreover, there has not been an intense integration related to humanity's goal as caliph on earth, with the goal of sustainability which nowadays campaigned more in western countries (socialism).

d) As for the constructors of the Islamic work ethics behaviour, the researchers previously tended to use standards of behavior that do not violate Islamic principles as constructs that reflect Islamic work ethics [5],[7]. Such as business activities that are in accordance with Islamic law. However, the element of intention and purpose in behavior (morality) and elements of unity (aqeedah) have not been equipped in formulating the Islamic work ethic standard.

\subsection{Research Statement}

Based on a number of problems that have been mentioned before, then this study tries to formulate a more relevance model among the three elements; business, human goals as caliphs, and global issues of sustainability. As well as formulating the link between sustainable goals and the importance of maintaining business continuity in Islam.

\subsection{Purpose of the Study}

The purpose of this study is to produce a clear picture of the role of sustainability goals in a business, especially the relationship between sustainability goals and business sustainability. So that global sustainability goals with the company's goals to achieve business sustainability can be aligned without colliding with each other due to differences in interests. Sustainability goals and the appropriate business strategy to achieve business sustainability are inseparable from the goal of mankind as a caliph on the earth, and inseparable from the way to achieve it. It must referring to the provisions of Islam. Therefore, this study also intends to integrate global elements of sustainability, business strategy, and Islamic principles, into a 
comprehensive scheme, from procedures (intentions, goals, and actions in accordance with Islamic principles) until achieving both the targets (sustainability and business sustainability).

\section{Method}

The qualitative approach is carried out by in-depth study of related literature, finding a connecting line that combines various elements, until finally the formulation of indicators that can reflect the related variables in a more comprehensive and relevant correlation. The literature study produced a roadmap of research model framework, developed from the relationship scheme of previous studies, with references in the form of pieces of work by the thoughts of several authors on related topics.

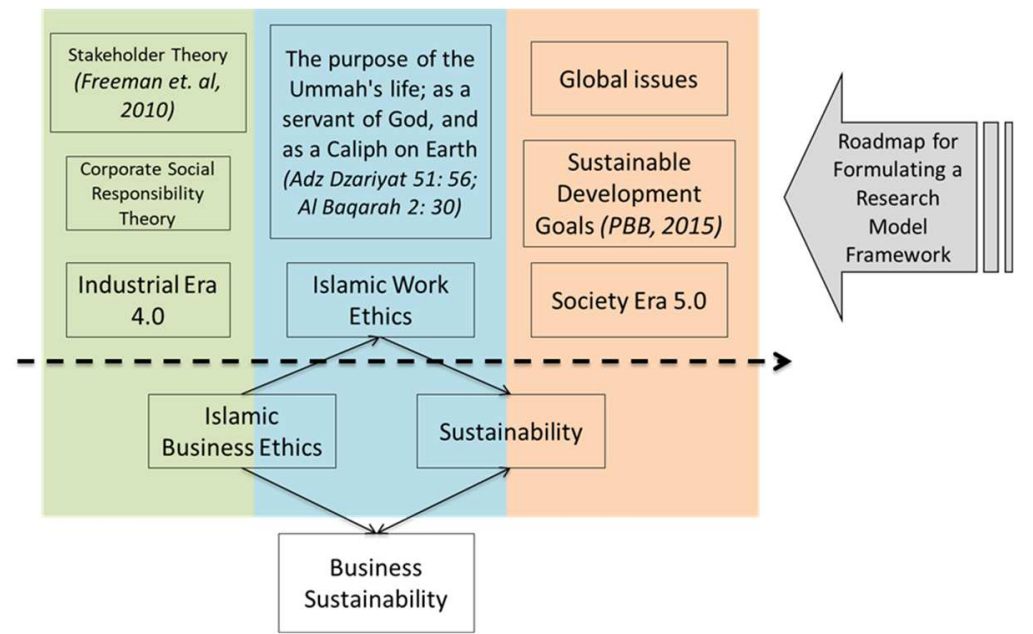

Fig. 2. Roadmap Research Model Framework

The roadmap is divided into 3 lines of charts with different colors. This shows the different sources of thought, namely from the business element that is represented by the theory of interests of a company's interests (stakeholder theory), the company's obligation to carry out social responsibility (CSR theory), and industrial development which is now increasingly modern. The second element is from the Islamic point of view, namely how should Muslims set their goals for life in this world, and place it in daily life, both everyday Muslims as people who work, and in establishing vision and mission as well as values that must be owned by companies that become their mandate. The third element refers to the social element, especially social issues that are global in nature or the main concern of the community at large, namely the goal of sustainable development which conventionally has become a joint responsibility.

Islamic business ethics can be said as a combination of business strategy with Islamic principles, while social awareness basically is not only based on existing social issues, but also back again is one of the responsibilities of Muslims as Caliphs on earth. As for the research statement mentioned in the previous chapter, the method can be drawn up to find the solution to each problem as follows. 
Problem 1: Analogous to the relationship of sustainability with business sustainability with the relationship between the company goals with the corporate social responsibility.

Problem 2: Complete indicators for sustainability and business sustainability.

Problem 3: Include elements of Islamic ethics in work activities, business strategy, and the Muslims' goals of their existence in this world.

Problem 4: Arrange indicators of Islamic Work Ethics and Islamic business ethics more comprehensively, by involving the element of monotheism (tauhid) and ihsan (justice).

\section{Discussion}

\subsection{Business Sustainability}

The main purpose of a business should be not a high profit, but the company's ability to run the business countinously, it is to make the business sustainable until next years [1]. From a business perspective, corporate sustainability can be defined as meeting the needs of stakeholders (shareholders, employees, clients, pressure groups, communities, etc.) [1],[8]. Corporate value based on sustainability orientation can provide strong ethical standards. The proper ethics foundation will develop proper strategic management. The strategy will involve sensitive ecological elements, enabling companies to meet the demands of various stakeholders, and does not separate the business matters with coporate social responsibility project [6].

To find out the goals and preferences of the company for their involvement in social issues, can use the following indicators; 1) what managers see as the main reason for companies to engage in activities that benefit the community; 2) whether the motives for the social initiatives of each company are different; 3) empirical support given to verify the answer of the first and second questions [9]. These three elements are important to note, because often large companies carry out social initiatives in social responsibility programs, with the hope of providing a good image in the community [6]. In this research must involve elements of the corporate image according to its own employees, as a form of staff engagement with the values carried by the company. It also involves elements of corporate performance as one of the main resources in keeping the company runs continuously (business sustainability).

Research in the hotel sector emphasizes the importance of maintaining sustainability, including the impact of their company in the future (the business sustainability). Optimal service in the hospitality service sector is not number one, but the concern to minimize waste as a form of maintaining sustainability for the future [4]. It means, concern to the sustainability matters is important in achieving the business sustainability. As for the research involve business ethics on the service standards, also related to policies that lead to legal and good policies (in Islam it is called Halal and Toyyib). It means the ways to achieve business sustainability are by concern to the sustainability, and by the proper business ethics [4].

\subsection{Sustainability (Sustainability Awareness)}

The global orientation on social issues arise since the Society 5.0 era [10]. This era is a derivative form of the international agenda of the Sustainable Development Goals (SDGs). 
SDGs agenda is grouped into 3 pillars i.e. social, environmental and economic. In Indonesia, Government added a pillar of law and governance [11]. These global issues become a concern of the government because it is in line with government objectives i.e. sustainable development, increasing inclusive and sustainable economic growth, ensuring a sustainable pattern of production and consumption, conserving and sustainably utilizing resources, access to affordable and sustainable energy, and protect forests [11]. As to achieve the objectives, all Indonesian citizens should participate too, both through their respective agencies and individually.

Sustainability has become a concern for many large companies including companies in Indonesia. Besides the regulations that require companies to do corporate social responsibility, some companies also recognize the importance of sustainable impacts so they voluntarily prepare sustainability reports. This sustainability report is commonly made by companies that can adverse the environment by their emissions or waste of water, air, and solid waste. The emmisions were caused by the company's operations. These companies include cement companies, transportation, manufacturing or mass production, fossil fuel use, and hospitality [4]. It means the companies that have had awareness of sustainability are companies that have a large impact on the environment.

Sustainability has a broader context than CSR activities carried out by many companies. Sustainability questions the company's business processes that must directly support shared sustainability goals, namely business processes that are environmentally friendly, oriented towards inclusive economic empowerment, and sustainable resource empowerment. Thus finally global goals such as sustainable development goals can be achieved.

Basically social responsibility is not only owned by large manufacture companies, but also the responsibility of every entity in the world to maintain the earth's sustainability. This is in line with one of the two human goals created on this world i.e. to become a caliph or leader / guardian on this earth (Al Baqarah, 2:30). Islam is a religion that not only regulates the relationship between humans and God, but also regulates the relationship among humans, as well as humans with the surrounding environment. Thus people must also aware about the sustainable issue [3].

Measuring sustainability achievement commonly used the statistic data [11],[12]. However this study tries to use the human perspective, which sustainability indicator must be converse to the proper measurement [10]. Indeed, the variable must be named as the sustainability awareness of the entity both individual and corporate.

\subsection{The Relationship of Sustainability Awareness and Business Sustainability}

Global sustainable development goal is part of the aim of Muslims as caliphs or guards on earth. This social goals is not only for self interest orientation nor the corporates'. The process or way of achieving these goals must be impulsive actions and not separate between company and individuals policies, with social responsibility. In other words, sustainability issues must be included as one of the considerations for every decision made by companies and individuals.

To achieve this goal, companies must maintain and grow their economic, social and environmental capital base (triple-bottom-line) [1],[8]. The three basic elements of sustainability can be developed to achieve business sustainability [6], as presented in Table 1 . 
Table 1. Adaptation and Modification of Sustainability Dimensions for Achieving Business Sustainability

\begin{tabular}{|c|c|c|}
\hline Dimension & Corporate Actions & Key Point \\
\hline $\begin{array}{l}\text { Eco-efficiency } \\
\text { (environmental } \\
\text { efficiency) }\end{array}$ & $\begin{array}{l}\text { use and manage the disposal of scarce resources, to } \\
\text { preserve the ecological environment }\end{array}$ & $\begin{array}{l}\text { Environmentally } \\
\text { friendly resources }\end{array}$ \\
\hline Social Efficiency & $\begin{array}{l}\text { optimal distribution of resources in the community, } \\
\text { taking into account all external costs and benefits, } \\
\text { as well as internal costs and benefits }\end{array}$ & $\begin{array}{l}\text { Human resource } \\
\text { management policies }\end{array}$ \\
\hline Eco-effectiveness & $\begin{array}{l}\text { transformation, a socially committed business } \\
\text { environment is characterized by a breakthrough in } \\
\text { innovation }\end{array}$ & $\begin{array}{l}\text { Use of technology and } \\
\text { innovation }\end{array}$ \\
\hline Social effectiveness & $\begin{array}{l}\text { continuing business commitments to behave } \\
\text { ethically and contribute to economic development, } \\
\text { while improving the quality of life of workers and } \\
\text { families in society and society }\end{array}$ & $\begin{array}{l}\text { corporate social } \\
\text { responsibility }\end{array}$ \\
\hline Adequacy & adequate conditions or quality & $\begin{array}{l}\text { Capacity of self } \\
\text { (company) }\end{array}$ \\
\hline $\begin{array}{l}\text { Ecological equity } \\
\text { (equality for the } \\
\text { long term) }\end{array}$ & $\begin{array}{l}\text { systems approach with a global perspective on the } \\
\text { use of human resources, economic development, } \\
\text { and the environment as equity owned by a company }\end{array}$ & $\begin{array}{l}\text { Engagement and } \\
\text { ownership of the } \\
\text { sustainability issue }\end{array}$ \\
\hline
\end{tabular}

\subsection{Islamic Ethics}

Ethics has a disadvantage because ethical standards will be different depending on the culture and norms belongs to each region [5]. Moreover it is unwise when we separate religious affairs from world affairs (secularism). Because basically Islam exists to be a guide in carrying out any actions relating to worship (ibadah) and actions related to world affairs such as working, doing business, cooperating, or behaving to others and the environment (muamalah) [5].

Thus Islamic ethics derives from the basic principles of the moral code specified in the Quran and Sunnah [5]. By standardization based on the Al Quran and As-Sunnah, the ethics standards will be the same in every place, fairly, and completely no lack. Because Al Quran is a complete law. Moreover, a Muslim cannot escape from these two main sources. The details of work ethics in Islam are not different from the details of morals in daily life [5].

Islam is a religion that not only regulates the relationship between humans and God, but also regulates the relationship among humans, as well as humans with the surrounding environment. This is written in the Islamic holy book namely Al Qur'an. The Qur'an, along with the Sunnah and Hadith of the Prophet Muhammad Peace be upon him (PBUH), is the main source of reference that governs all human actions. Moreover, it has been stipulated in the Qur'an that the purpose of mankind is to worship Allah SWT, and to become a caliph on earth. The humans' objective as caliph is in line with the goal of sustainability, it is to guard the earth.

Many researchers have formulated indicators that can reflect the behavior of Islamic work ethics such as; 1) Laziness is bad, 2) Dedication to working to benefit ourselves and others, 3) Good work benefits both yourself and others, 4) Justice and generosity in the workplace are conditions that are needed for the welfare of the community, 5) Producing more than enough to meet one's personal needs contributes to the welfare of society as a whole, 6) A person must exercise according to his best abilities, 7) Work is not an end in itself but a means to 
encourage personal growth and social relations, 8) Life has no meaning without working, 9) More free time for the community, 10) Human relations in organizations must be emphasized and encouraged, 11) Work allows humans to control nature, 12) Creative work is the source of happiness and achievement, 13) Everyone who works is more likely to advance in life, 14) Work gives someone the opportunity to be independent, 15) Successful people are people who meet deadlines at work, 16) Someone must continue to work hard to fulfill responsibilities, 17) The value of work comes from the intention that accompanies it rather than the result [13]-[17]. The indicators mentioned above are representative of Islamic values manifested in work activities such as team working culture, commitment and responsibility, intellectual ownership and trusteeship [18].

However, as part of morality, Islamic work ethics must be developed on two sides in a balanced manner, namely the side of human relations with Allah (mu'amalah ma'al khaliq) and the side of human relations with fellow beings (mu'amalah ma'al khalq) [19],[20, p. 93]. Involving the human relationship with God emphasizes the need to complete a construct that reflects Islamic work ethics with a value-based view [18]. That involves the element of monotheism and involving God in every action, placing the matter of worship directly between worship through muamalah, and providing faith in destiny [20].

Involving the divine element in every reflection of Islamic work ethics is considered important so that the good values that have been put forward do not become free values without a clear purpose (lillahita'ala). Moreover, an activity can be considered a virtuous deed not only seen from its good values (husnul fi'liyyah), but also from the sincerity of intention (husnul fa'iliyyah) [20, p. 93]. Islamic work ethics becomes the base of someone's acts. What is done is seen as a commendable act also has a value of worship towards Allah S.W.T. So that work will be carried out with sincerity, enthusiasm, gratitude, open heart, proactive, giving the best, honesty, fairness, caring for others, being responsible, and virtue oriented (al Ihsan) [20],[21].

Ihsan is the basic morality of civil economy. Ihsan's attitude means always wanting to improve and do the best, and always feel watched by God in everything we do. With knowledge and attitude, one does not only act according to Islamic ethics by prioritizing primary behavior, perfect behavior, or optimally in carrying out every action and economic attitude and behavior that prioritizes social interests (the shariah side of the shariah), but also has the purpose of the hereafter as the main purpose (ihsan from the side of ruhiyah).

\subsection{The Relationship of Islamic Work Ethics toward Sustainability Awareness and Business Sustainability}

Previous studies distinguish between Islamic ethical behavior in working or doing business, with one's Islamic ethical behavior as an individual. However, it does not involve the role of the company itself as an entity that has a great ability to lead its employees to act according to Islamic ethics. Agencies that uphold Islamic values as corporate values can not only intervene in the perceptions of their employees to participate in behaving according to Islamic ethics, but to give rights and obligations fairly. The Islamic culture pioneered by the company itself not only creates a pleasant and Islamic work environment, but also can increase ties with various parties, especially to achieve the company's sustainable business efforts.

Research related to Islamic work ethics has often been carried out in the previous period. Among them is research related to how the Islamic work ethic towards company or organizational policies perceived by workers, towards the sense of ownership of the company, 
can ultimately improve the performance of the workers themselves. In this viewpoint, the main points of Islamic work ethics tend to be the values held by employees so that they see external conditions with a positive perspective, which raises the habit of qanaah (on company policy) and increases the sense of responsibility towards the company (ownership). With the ability of Islamic work ethics to increase employee engagement with the company, it will improve their performance [6],[7]. As for the concept of business sustainability, commitment and loyalty of human resources is a long-term investment that can maintain business continuity [22, p. 78], especially if human resources have an Islamic work ethic.

Islamic work ethic behavior is not just to work well for the sustainability of the company's business, as one of the efforts to achieve the pleasure of Allah SWT, but also needs to pay attention to the duty of humans as caliphs on earth. Thus good deeds are not enough, but also pay attention to the long-term effects of the actions taken. As a global issue related to sustainable development goals which are the joint responsibility of the parties, both individuals and agencies [11].

\subsection{The Relationship of Islamic Business Ethics toward Sustainability Awareness and Business Sustainability}

In the conventional scientific order, business ethics can be reflected in the company's compliance with established rules. Some company provisions relating to business patterns that conform to ethics are provisions related to corporate governance, while company provisions that are in line with the principle of responsibility for broader things (sustainability) are provisions related to the obligation to carry out social responsibilities.

In most cases, the law will regulate various provisions in doing business including the standard of social responsibility that needs to be done, while ethical practices will consider sustainable practices that exceed these regulated obligations. Ethical sustainability will actively define and manage social development and concern for humans and the planet. This will transcend good statements to be defined as strategic obligations that are actively managed and monitored throughout the organization [4].

Business activities in general are activities to increase added value through the process of production, trade or service delivery. The purpose of this activity is solely to increase the maximum profit, without considering spiritual values. The business activities according to Islam are not merely to increase profit materially [22, p. 78]. In Islam, profit or benefit must not only be seen from the material results, but also must be seen from how to obtain and use these results. Referring to (QS: Al-Jum'ah 62: 10), Allah commands to seek His gift (bless) instead of profit. The assets or profit obtained from the business must be accounted for as God's gift, it must be obtained in the right way and used in the right way [21].

The way to do business in accordance with Islamic principles is to prioritize fairness and transparency. Fair business is a business that is free from tyranny against anyone. By being fair, no one will be persecuted. Employees, consumers, customers, superiors, company owners, or anyone will undergo each transaction with a pleasant feeling. While transparent is a manifestation of honest business. With good transparency, there will be suspicion from each other. It should be noted that destructive performance is a bad prejudice to each other so that various liver diseases arise that will damage the atmosphere and work performance [22, p. 32].

In order for the company's goals to be achieved, a company as a forum for business activities must be able to: 1 . a place of worship, a corporate place of worship and as a place for jihad. 2. a place of wealth, namely corporate as a place to manage the company to gain wealth, as a place to realize prosperity, and as a place to realize the afterlife world. 3. a place of 
warfare that is corporate as an arena of warfare against the business of sunset, and the war against poverty [23].

The explanation above is in line with the five axioms of Islamic economic ethics in general, namely: oneness (tauhid), free will (free will), proportionality (eqilibrium), and responsibility (responsibility), and virtue (ihsan). The five axioms can be used as a basis in building business ethics in the context of Islam [24, p. 53]. By involving Islamic business ethics factors means the object of research only in institutions that uphold Islamic values as their corporate value. Moreover, in the work and business circle, not necessarily Muslim traders and businessmen (as owners of companies) can deal with others in accordance with muamalah fiqh (Islamic ethics) [5].

A Muslim in playing his role on earth, both as an employer and as an employee, not only needs to pay attention to the halal and prohibition of what he does, but also to pay attention to the ethical, wrong and right, good and bad, fair and unfair, and even need to pay attention to in terms of their intentions and goals [5]. Therefore, the right business ethics in an effort to achieve both business continuity and the sustainability, is the business ethics involving the Islamic principle. As for the Islamic principle must be implemented in the business ethics and the workers'.

As for reflecting business sustainability, the measurement of the performance using a single dimension is unable to provide the comprehensive score. Performance measurement should integrate diverse measurement dimensions such as dimensions of growth and dimensions of capability [25]. In the end, business sustainability cannot be measured only by profit movements and company growth. It must be measured comprehensively with the support of the people in the company. To commit supporting the companies that has embraced Islamic values as a vision and value of their company.

In business ethics principles for sustainability, ethics is not only a behavior that must be owned by the company because it is the basis of good business practices, but also needs to pay attention to business ethics and sustainability principles which means paying attention to its impact in the future. That is not only applying good and above standard business practices, but also long-term oriented and for the benefit of all parties (stakeholders), namely by minimizing waste (a form of sustainability [4]. This further emphasizes business ethics for sustainability not only related to service standards, but also policies that lead to legal as well as good (halal lan toyyib), not just legal.

\subsection{Conceptual Framework}

Companies that make Al Quran and al Hadith as the main guidelines in running their companies will make Islamic values as corporate values, and can even be stated in the company's vision and mission. The company also has the power to disseminate this vision and mission to all of its employees, in order to achieve the essential goals as stated in the vision and mission. Company values that are in accordance with Islamic principles will also be instilled in every employee so that company employees will behave and act in accordance with Islamic ethics. Thus, Islamic business ethics is not only reflected in the established organizational culture, but will also intervene in employee performance behavior, and provide a comprehensive picture of the goals to be achieved, so that ultimately these various elements will be able to maintain business continuity, in order to continue to ground Islam. .

Islamic ethics means falah or benefit as the ultimate goal, and realizing that every individual has a duty as caliph on earth. So a company that is founded by individuals to achieve Islamic goals, should pay attention to social interests as one of the company's long- 
term responsibilities, which can be achieved with various policies that benefit all parties for the long term (sustainable goals).

Based on the explanation regarding sustainability goals, business sustainability goals, and Islamic ethics both by the company and by employees, a thinking framework model can be created as presented in Figure 3. The figure shows the harmonization of global sustainable goals with the business objectives of sustainability, driven by a culture of Islamic work ethics and Islamic business ethics.

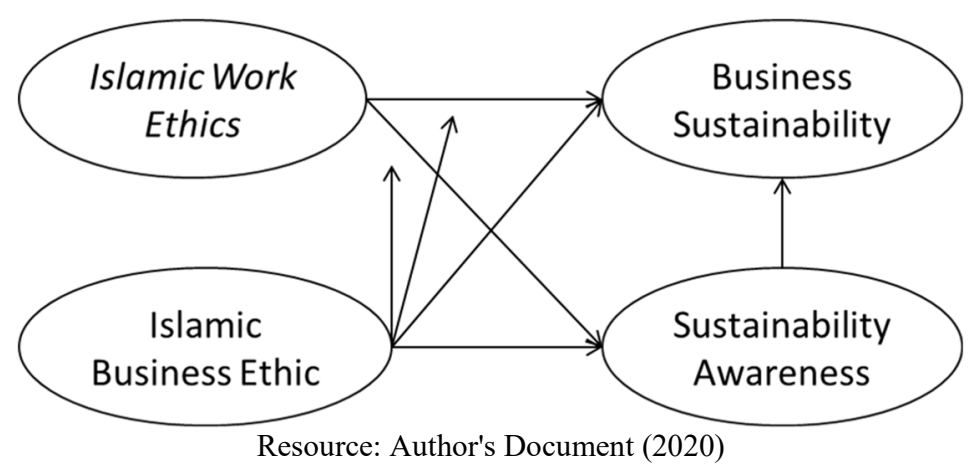

Fig. 3. Conceptual Framework Model

\section{Conclusion}

Sustainability goals and an appropriate business strategy to achieve business sustainability. For Muslims those are inseparable from the goal of mankind as a caliph (khalifah) on the earth, and inseparable from the way to achieve those goals. The way must referring to the provisions of Islam. Therefore, this study intends to integrate global elements of sustainability, business strategy, and Islamic principles, into a comprehensive scheme. It is by considerate the procedures (intentions, goals, and actions in accordance with Islamic principles) until achieving both the targets (sustainability and business sustainability).

Ethics has a disadvantage because ethical standards will be different depending on the culture and norms belongs to each region [5]. While Islamic ethics derives from the basic principles of the moral code specified in the Quran and Sunnah [5]. By standardization based on the Al Quran and As-Sunnah, the ethics standards will be the same in every place, fairly, and completely no lack. Because Al Quran is a complete law. Moreover, a Muslim cannot escape from these two main sources. The details of work ethics in Islam are not different from the details of morals in daily life [5].

By basing on Islamic principles, Islamic work ethics becomes the base of someone's acts. What is done is seen as a commendable act also has a value of worship towards Allah S.W.T. So that work will be carried out with sincerity, enthusiasm, gratitude, open heart, proactive, giving the best, honesty, fairness, caring for others, being responsible, and virtue oriented (al Ihsan) [20],[21]. By involving Islamic business ethics factors means the object of research only in institutions that uphold Islamic values as their corporate value. Moreover, in the work and business circle, not necessarily Muslim traders and businessmen (as owners of companies) can deal with others in accordance with muamalah fiqh (Islamic ethics) [5]. 


\section{References}

[1] R. E. Freeman, J. S. Harrison, A. C. Wicks, B. L. Parmar, and S. de Colle, Stakeholder theory: the state of the art. Cambridge: Cambridge University Press, 2010.

[2] N. Ghoniyah and S. Hartono, 'The Contribution of Islamic Banks towards the Achievement of Sustainable Development Goals: The Case of Indonesia', Econ. Financ. Indones., vol. 65, no. 2, pp. 93-110, Dec. 2019.

[3] Financial Ferivices Authority, 'Tujuan Pembangunan Berkelanjutan', Otoritas Jasa Keuangan, 2017. [Online]. Available: https://www.ojk.go.id/sustainablefinance/id/publikasi/prinsip-dan-kesepakatan-internasional/Pages/TujuanPembangunan-Berkelanjutan.aspx. [Accessed: 01-Jun-2018].

[4] C. Lashley, 'Business ethics and sustainability', Res. Hosp. Manag., vol. 6, no. 1, pp. $1-7,2016$.

[5] S. A. Abuznaid, 'Business ethics in Islam: the glaring gap in practice', Int. J. Islam. Middle East. Financ. Manag., vol. 2, no. 4, pp. 278-288, Nov. 2009.

[6] A. Marina, S. Imam Wahjono, and S. I. Wahjono, 'BUSINESS ETHICS FOR BUSINESS SUSTAINABILITY IN MUHAMMADIYAH HOSPITAL: EVIDENCE FROM PONOROGO, INDONESIA', J. Indones. Econ. Bus., vol. 32, no. 3, p. 178, Dec. 2017.

[7] J. Mohammad, F. Quoquab, F. Idris, M. Al-Jabari, N. Hussin, and R. Wishah, 'The Relationship between Islamic Work Ethic and Workplace Outcome', Pers. Rev., vol. 47, no. 7, pp. 1286-1308, Nov. 2018.

[8] T. N. Gladwin, J. J. Kennelly, and T.-S. Krause, 'Shifting Paradigms for Sustainable Development: Implications for Management Theory and Research', Acad. Manag. Rev., vol. 20, no. 4, pp. 874-907, Oct. 1995.

[9] P. S. Brønn and D. Vidaver-Cohen, 'Corporate Motives for Social Initiative: Legitimacy, Sustainability, or the Bottom Line?', J. Bus. Ethics, vol. 87, no. S1, pp. 91-109, Apr. 2009.

[10] M. Fukuyama, 'Society 5.0: Aiming for a New Human-Centered Society', Japan, 2018.

[11] Central Bureau of Statistics, 'Potret Awal Tujuan Pembangunan Berkelanjutan (Sustainable Development Goals) di Indonesia. Kajian Indikator Lintas Sektor', Jakarta, 2016.

[12] Central Bureau of Statistics, 'Statistical Yearbook of Indonesia 2018', Jakarta, 2018.

[13] N. Kumar and R. Che Rose, 'The impact of knowledge sharing and Islamic work ethic on innovation capability', Cross Cult. Manag. An Int. J., vol. 19, no. 2, pp. 142-165, Apr. 2012.

[14] N. Kumar and R. Che Rose, 'Examining the link between Islamic work ethic and innovation capability', J. Manag. Dev., vol. 29, no. 1, pp. 79-93, Jan. 2010.

[15] D. A. Yousef, 'The Islamic work ethic as a mediator of the relationship between locus of control, role conflict and role ambiguity - A study in an Islamic country setting', $J$. Manag. Psychol., vol. 15, no. 4, pp. 283-298, Jun. 2000.

[16] A. J. Ali and A. A. Al-Kazemi, 'Islamic work ethic in Kuwait', Cross Cult. Manag. An Int. J., vol. 14, no. 2, pp. 93-104, May 2007.

[17] A. J. Ali and A. Al-Owaihan, 'Islamic work ethic: a critical review', Cross Cult. Manag. An Int. J., vol. 15, no. 1, pp. 5-19, Feb. 2008.

[18] P. Akhavan, M. Ramezan, J. Yazdi Moghaddam, and G. Mehralian, 'Exploring the relationship between ethics, knowledge creation and organizational performance', VINE, vol. 44, no. 1, pp. 42-58, Feb. 2014. 
[19] C. Darmawan, Kiat Sukses Manajemen Rasulullah. Bandung: Khazanah Intelektual, 2006.

[20] A. J. Asifudin, Etos Kerja Islami. Surakarta: Muhammadiyah University Press, 2004.

[21] N. Ghoniyah, 'Pengaruh Tata Kelola Perusahaan dan Etika Kerja Islami terhadap Kinerja Keuangan dan Kesejahteraan Karyawan pada Perusahaan Pakaian Jadi di Jawa Tengah', Airlangga University, 2010.

[22] A. Gymnastiar, Etika Bisnis MQ: Kejujuran, Kebersihan Hati, Kebermanfaatan. Bandung: Khas MQ, 2006.

[23] K. Alwan, 'Makalah Kuliah Umum Tata Kelola Perusahaan Islami', Surabaya, 2007.

[24] Muhammad, Etika Bisnis Islami. Yogyakarta: UPP AMP YKPM, 2004.

[25] M. Bhargava, C. Dubelaar, and S. Ramaswami, 'Reconciling diverse measures of performance: A conceptual framework and test of a methodology', J. Bus. Res., vol. 31, no. 2-3, pp. 235-246, Oct. 1994. 